\title{
İlköğretim Sekizinci Sınıf Öğrencilerinin Sosyal Sermaye Profili, Sosyal Sermaye ve Başarı Durumunun Çeşitli Demografik Değişkenlere Göre Değerlendirilmesi: Antalya Örneği*
}

\author{
Faik ARDAHAN ${ }^{* *}$
}

\author{
Melek Nurcan EZICí $\dot{I}^{* * *}$
}

\begin{abstract}
Öz
Bu çalışmanın amacı Antalya örneğinde ilköğretim sekizinci sınıf öğrencilerinin sosyal sermaye profillerini belirlemek, sosyal sermaye ve başarı durumlarını çeşitli demografik değişkenlere göre irdelemektir. Çalışmada Huang, L. (2008) tarafından geliştirilen, Ardahan ve Ezici (2014) tarafından Türkçe adaptasyonu yapılan, İlköğretim İkinci Kademe Öğrencileri Sosyal Sermaye Ölçeği ve Bilgin ve Kaynak (2008) tarafından geliştirilen Başarı Ölçeği kullanılmıştır. Tanımlayıcı araştırma modelinde olan çalışmanın örneklem grubu; Antalya'da bulunan üç devlet (Beşkonak İÖO, Dr. Galip Kahraman İÖO, Barbaros İÖO) ve iki özel okul (AKEV Koleji İÖO, Antalya Koleji İÖO) toplam beş farklı ilköğretim okulunun sekizinci sınıfındaki tüm (162 kız ve 163 erkek, toplam 325) öğrencilerden oluşmaktadır. Verilerin değerlendirilmesinde; betimsel istatistiklerin yanında, Tek Yönlü Varyans Analizi, Bağımsız Örneklem t testi, iki değişken arasındaki korelasyona bakmak için Pearson Corelation Test kullanılmıştır. Farklılığı yaratan grup ya da grupların belirlenmesinde Tukey-b testi kullanılmış, sonuçlar 0.01 ve 0.05 anlamlılık düzeylerinde değerlendirilmiştir. Sonuç olarak; sosyal sermaye ve akademik başarı arasında anlamlı bir ilişki vardır. Öğrencilerin sosyal sermayelerini geleceğe yatırım olarak görüp onu arttırmanın yolları aranmalıdır. Bir öğrencinin veya toplumun sosyal sermaye düzeyi arttırıldığında başarı da bununla birlikte gelecektir. Diğer taraftan başarı durumu ile okullar arasında bir farklılık vardır. Başarı düzeyi yüksek okullar daha çok gelir düzeyi düşük sosyal çevresi olan ve öğrenci başarısı üzerine yatırım yapmış okullardır. Anne ve babanın eğitim düzeyinin ve gelir düzeylerinin düşük olması, öğrencinin ailede, kendi sosyal çevresinde bulamadığı akademik desteği almak için öğrencileri öğretmenleriyle daha etkileşim içinde, anlamlı ve doyumlu bir ilişkiye zorlarken, ebeveynlerin okula ve eğitim süreçlerine daha fazla dahil olması, öğrenci ile ilişkisi ve etkileşimin artması doğal olarak öğrencinin akademik başarısını da arttırmaktadır.
\end{abstract}

Anahtar Kelimeler: Mutlak Başarı, Algılanan Başarı, Sosyal Sermaye, İlköğretim İkinci Kademe Öğrencileri.

\footnotetext{
* Bu makale 6-8 Haziran 2014 tarihinde İstanbul/Türkiye' de organize edilen ERPA, International Congress on Education' da sözel olarak sunulan bildirinin geliştirilmiş halidir.

** Doç. Dr., Akdeniz Üniversitesi, Beden Eğitimi ve Spor Yüksek Okulu, Rekreasyon Bölümü, ardahan@akdeniz.edu.tr

*** Akdeniz Üniversitesi, Beden Eğitimi ve Spor Yüksek Okulu, Öğretmenlik Bölümü
} 


\title{
The Social Capital Profile of the Eighth Class Students, Examine the Social Capital and Student Achievements With Respect to Some Demographics Variable: Antalya Case
}

\begin{abstract}
The purpose of the present study is to define the profile of Eighth Class Students and to examine the social capital and student achievements level of students with respect to some demographic variables. In this study, Social Capital Scale which was developed by Huang (2008) and adapted to Turkish population by Ardahan and Ezici (2014) and achievement inventory developed by Bilgin and Kaynak (2008) were used. This is a descriptive study and sampling group consisted of 162 girls, 163 boys and totally 325 students who were studying in the five different schools (three states, two private schools) which have different environments. In order to analyze the data, the descriptive statistics methods, ANOVA test, and Independent Samples $t$ test, for correlation Pearson Correlation Test and to explain relation between dependent and independent variables Tukey-b test was used. Results have been assessed according to significant levels 0.01 and 0.05 . As a result of this study, the strong correlation was found between social capital level in all sub dimension also) and students achievements. It is vitally important that social capital must be accepted as an investment and must be examined to increase the level of it. When social capital level of a student or society was increased, achievements would follow it. On the other hand, there was statistically meaningful difference between school types on the student's achievements level in favor of schools which has disadvantages environment and which students family has low income or which have made adequate investment for students achievements. The parents who has lower education level and lower income level, forces the student to establish adequate or more relation with teacher to make compensation of academic support which cannot be realized in family or social environment of students. When family attendance to school and the quality and satisfaction level of parent-student's relation increase, it affects positively the student's achievement.
\end{abstract}

Keywords: Real Achievement, Perceived Achievement, Social Capital, Second Grade Students.

\section{GíRiş}

Sosyal sermaye kavramı, yerli ve yabancı literatürde sosyoloji, işletmecilik ve yönetim bilimleri boyutuyla birçok açıdan sorgulanmış, fakat çok az çalışmada sosyal sermaye akademik başarı ile ilişkilendirilerek sorgulanmıştır. Bireylerin kendi aralarında yarattıkları ilişkinin düzeyi ve kalitesi direkt ya da endirekt olarak bireyin yaşamındaki birçok olayı, süreci, durumu etkilemekte ve doğal olarak da bireylerin başarı düzeylerini etkilemektedir.

Sosyal Sermaye düzeyinin yüksek olduğu toplumlarda bireylerin gelişmiş ve yüksek sosyal sermayelerinden kaynaklı yaratılan katma değer ve rekabet avantajlarının da yüksek olması, beraberinde iş başarısı, sporda, sanatta, kültürel katma değer yaratma ve onları talep etmede de nitelikli artışı beraberinde getirmiştir. Bu sebeple bu çalışma öğrencilerin sosyal sermayeleri ile başarıları arasındaki ilişkiyi belirlemeye yönelik bir çalışmadır.

\subsection{Akademik Başarı}

Türkiye'de her çocuk, üniversite eğitimi ve meslek yaşamına başlamadan önce 12 yıl süren ve genellikle merkezi otorite tarafından belirlenmiş bir müfredatın uygulandığ 1 ve prensip olarak ülkenin her yerinde "eğitimde fırsat eşitliği ve uygulamaların olduğunu" savunan herkes için ücretsiz olan temel eğitim programından geçer. Eğitimde fırsat eşitliği politikalarının ülkemizde derin bir geçmişi vardır ve resmi anlamda eşitliğin yaratılması yörenin, ailenin, ekonomik, sosyal ve kültürel geçmişi, cinsiyeti, yaşadığı yer veya özel gereksinimleri 
ne olursa olsun her çocuğun eğitim sistemine dahil edilmesini destekler/zorunlu kılar.

Başarl; bir durumu ve/veya bir sonucu ifade etmek için değil bir süreç üzerine yapılandırılmış kültürel, sportif, sanatsal, akademik, mesleki, sağlık ve hayatın akıp gittiği her yerdeki her şeyle ilişkilendirilebilecek, bireyin kendisinin tanımladığı ve/veya başkaları tarafından tanımlanan hedeflere ulaşması, kendi yetenek ve becerilerini en iyi şekilde göstermesi, karş1laşılan problemlerin üstesinden gelebilmesi tanımlanabilir (Ardahan, 2013). Akademik başarı ise içeriği ve akışı tanımlanmış müfredatı, tanımlanmış müfredat döneminde, eğitimin beklenen faydalarını elde etmek, bireyi yaşamda güçlü kılacak donanımlarla tamamlama olarak (Keskin ve Sezgin, 2010) veya bireyin duyuşsal ve psikomotor gelişiminin dışında kalan, bilişsel düzeyindeki ve bütün program alanlarında kazanılan/gösterilen davranış değişimlerini ifade eder (Erdoğdu, 2006). Akademik başarı öğrencinin tüm yaşamını etkileyen/belirleyen bir sonuçtur. Bu sebeple neden sonuç ilişkisi içinde başarıya etki eden tüm faktörlerin yok sayılmadan eğitimin tarafı olan birimler, bireyler, kurumlar ve kaynaklar açısından etkin yönetilmesi gereklidir. Bu tanımlar perspektifinde bakıldığında "başarı" kavramı iki farklı başarı sürecinin toplamı olarak görülmelidir. Birincisi mutlak başarıdır. $\mathrm{Bu}$ boyutuyla başarı objektiftir, rakamlarla ifade edilen hedeflerin rakamlarla ifade edilen gerçekleştirilme durumudur. İkincisi ise, algılanan başarıdır. Bu boyutuyla başarı sübjektiftir, içinde olunan koşullar, kişinin, ailenin, toplumun fiziksel, ruhsal, duygusal koşulları ve diğer birçok faktörden etkilenen içsel ve dışsal faktörle belirlenen, etkilenen durumlarda ulaşılan hedef düzeyidir. Başarı denildiğinde hem mutlak hem de algılanan başarının beraber düşünülmesi gereklidir.
Eğitimde öğrencinin başarısını ve okula olan devamını etkileyen çok sayıda faktör vardır. Bunlar öğrencinin öğrenme kapasitesi, kişiliği, yetenek ve becerileri, paradigması, aile ve çevresindeki kişilerin eğitimden beklentileri, onlarla yarattı̆̆ 1 etkileşim, sahip olduğu ilişkinin, işbirliğinin düzeyi ve kalitesidir. Ayrıca eğitimin amacına ve akademik başarıya ulaşabilmek için öğrencinin ailesi, arkadaşları, öğretmenleri ve ailesinin eğitim sürecindeki kişi ve kurumlarla yarattığ 1 uyum ve yaptığı işbirliği de önemlidir (Huang, 2008).

Bunlara ilave olarak; birçok toplumda, öğrencinin başarısında ebeveyne dayalı eğitim sistemi ve ailenin ekonomik durumunun etkisinin olduğunda ısrar edilirken, çocukların eğitim çıtılarının (öğrenme ve başarı düzeyindeki) farklılı̆̆ının açıklanmasında ailenin etkisini esas alan çalışmalar hala yeterli değildir (BuruBellat, 2004). Birçok araştırmacı; çocuğun okuldaki sosyal ve akademik başarısı ve okula devaminda; ailenin ekonomik ve insani sermayesinin etkilerine ilave olarak, evin, yaşanılan muhitin sosyal yapısının, güven ve insana dayalı özellikler toplamının, ailenin ne zamandır aynı yerde oturulduğunun, ebeveynlerin eğitimle ilgili beklentilerinin, ebeveynlerin diğer ebeveynlerle çocukların eğitimi konusundaki etkileşim, işbirliğinin, okul aktiviteleri hakkında ebeveyn-çocuk etkileşiminin, devam edilen okulun özelliklerinin, okul değiştirmenin, okul etkinliklerine ebeveynlerin dahil olmasının ve ebeveyn ile okul arasındaki akademik temasların etkilediğine inanmaktadır (Meier, 1999; Sandefur ve Wells, 1999; Güzel ve Berberoglu, 2005; Sandefur ve diğ., 2006). Elbette bu faktörlere ilave olarak; okulun nerede olduğu, sahip olunan kaynaklardaki farklılık, içsel sosyal etkileşim, okul çevresi, öğrencinin eğitimsel norm ve amaçları öğrencinin eğitim başarısını ve buna bağlı olarak da okula olan devamlılığını etkileyen önemli faktörlerdir (Morgen, 2001). Bu sebeple birçok araştırmacı 
artık, öğrencinin sosyo-ekonomik geçmişi, aile bireyleriyle, akranlarıyla, diğer insanlarla olan etkileşiminin öğrencinin akademik başarısında ve okula devam etmesinde okulun yarattığ etkiyi geçtiğini savunmaktadırlar (Thrupp, 1999; Breen ve Jonsson, 2005).

Birçok araştırmacl; ailedeki insan sermayesi yeterli hatta yüksek olsa bile aile içinde eğer ebeveyn-çocuk etkileşimi yeterli değilse bu durum çocuğun okulda başarılı olmasını sağlamayacağını savunur. Diğer bir deyişle çocuğun okuldaki başarısı büyük ölçüde ailedeki insan sermayesinin (eğitim düzeyi, bilgi düzeyi) yüksek olmasına değil büyük ölçüde ilişki sermayesi veya sosyal sermayenin varlığı ve yüksek olmasına bağlıdır (Teachman ve diğ. 1996). Bazı araştırmacılar çocuğun okul başarısında çocuk-aile etkileşim ve iletişim düzeyinin yeterli olamayacağı, başarının öğretmenleriyle kurduğu iletişim düzeyinin de belirlendiğini savunmaktadır. Çocuğun aile dışında kurgulayabildiği ilişkinin varlığı, düzeyi ve kalitesi çocuğun gelişmesini de büyük ölçüde etkilemektedir (McDonough, 1997; Harding, 2003). Aile içi uyum ve ailenin çocuğu destekleyici yaklaşımlarının, aile bireylerinin öğrencinin okul etkinliklerinden haberdar olması hatta düzenli olarak katılmasının çocuğun akademik ve sosyal başarısında önemi büyüktür (Çelenk, 2003).

Hangi türde olursa olsun başarı bazı durumlarda ihtiyaç, güdü ve hatta yüksek düzeyli motivasyon etkisi olan bir kavramdır. Başarı güdüsü ve başarma arzusu yüksek olan bireylerde nitelikli çaba ortaya koyarak bireylerin profesyonel olan ve olmayan hedeflerine ulaşmaları her türlü mental, fiziksel ve psikolojik zorluklarla başa çıkmalarını da kolaylaştırmaktadır. Bu sebeple başarma güdüsü yüksek olan bireylerin başarma güdüleri yaşamın birçok alanında ön plana çıkar. Başarı ihtiyacı bireylerin kendilerine tanımlanan ve/veya kendi ta- nımladıkları hedeflere odaklanarak hatta hedeflerle bütünleşerek bireylerin mesleki, görev, sanat, spor, sağlık, akademik gibi birçok alanda başarılarının artmasını sağlayan önemli bir faktördür (Kaya ve Selçuk, 2007).

\subsection{Sosyal Sermaye}

Sosyoloji, eğitim ve yönetim konusunda son zamanlarda birçok araştırmacının ve uygulamacının ilgisini çeken Sosyal sermaye kavramı ilk James Coleman (1988) tarafından çocukların eğitim başarılarını etkileyen bir faktör olarak ele alınmıştır. Coleman bu çalışmasında, çocuğun akademik başarısına ve okula olan ilgisine; ailenin geliri, çocuğun ve ailesinin wellbeing (iyi olma hali), ebeveynin akademik desteği ve eğitimsel gelişmişliğinin yanında en az onlar kadar değerli olan çocuğun ailesi, arkadaşları, akranları, toplum ve okulla kurguladığı, sürdürdüğü ilişkinin düzeyinin belirleyici olduğunu savunmaktadır. Coleman (1988) Sosyal sermayeyi; "birçok faktörden etkilenen ve birçok faktörü etkileyen bireyler arası ilişkilerin belirlediği ve yarattığı, bireylerin bir arada nasıl/neden olduğunu açıklamayı başarabilen bir araçtır". Bu tanımın dişında; Sosyal sermaye Putnam ve diğ. (1993); "toplumsal norm, güven ve sosyal ağların oluşturduğu sosyal ilişkiler ve sosyal organizasyonların toplamı", Fukuyama (1999); sosyal sermayeyi "bireyler arasında işbirliği ve iletişimle yaratılan, içtenlik, gönüllülük ve karşllıklı samimiyetin olduğu değerler birliği" ve Heral (2006); "ortak amaca ulaşabilmek için bireylerin kendi aralarında karşılıklı yarattıkları birey, grup ve/veya örgütler olarak gerçekleştirilen bir arada çalışma yeteneği”, Lin (2000); “sosyal ilişkilerin içine gömülmüş getiri beklenen yatırım ve kaynak kullanımı" tanımlanmıştır. Tanımların ortak noktalarından hareket edildiğinde, Sosyal sermayenin öğelerini; bireylerin kendi aralarında ve kurumlarla yarattıkları ilişki ağı, aidiyet duygusu, güven ve işbirliği olarak dört 
kategoride ele almak mümkündür. Sosyal sermayenin eğitim ortamlarında geliştirilmesi için okul içi ve çevresindeki bireye ve çevreye duyulan güven ortamının oluşturulması ve güven düzeyinin arttırılması, öğrenci, ebeveyn, öğretmen, okul yönetimi, eğitim sisteminde rol alan diğer kişi ve kurumlar, siyasiler gibi eğitimin tarafları arasındaki iletişimi ve etkileşimi geliştirmek, teşvik etmek, bireylerin bir araya gelebilecekleri formel ve/veya informel sosyal ortamlar hazırlamak ve işbirliğini özendirmek gerekir. Sosyal sermayenin geliştirilmesi, başta okul yöneticileri olmak üzere eğitimin taraflarının liderlik rolleri üstlenmesini gerektirmektedir.

Coleman'ın savunduğu ve ortaya attı̆g konular dışında ve yanında sosyal sermaye konusunda çok fazla çalışma yapılmıştır. Bazı yazarlar sosyal sermayeyi yapisal ve bireyler ve kurumlar arasında yaratılan ilişkiye dayalı olduğunu savunurken (Teachman ve diğ., 1996) bazıları da sosyal sermayenin bireylerin kendi aralarında ve kurumlarla gerçekleştirdikleri ilişki ile bireylerin amaçlarına ulaşmasını ve onların geliştirilmesini sağlayacak kaynak kullanımından oluşan iki bileşeni olduğunu savunmuşlardır (Schoen ve diğ., 1997). Bu bakış açılarının yanında Lin (2000) sosyal sermayeyi bir yatırım ve sosyal ilişkilerden beslenen bir girdi olarak görmüş, Sandefur ve Laumann (1998) ise sosyal sermayeyi form ve faydalardan oluşan iki boyut olarak ele almışır. Huang (2008) öğrencilerin sosyal sermayesini üç bileşenin oluşturduğunu savunmuştur. Bunlar; öğrencilerin ailesindeki insan ve ekonomik sermayesi, öğrencinin içinde olduğu ve etkilendiği toplumdaki insan ve ekonomik sermaye, ve üçüncü olarak da öğrencinin okulundaki insan ve ekonomik sermayedir. Her üç bileşende de insan sermayesi; insanların kendi aralarında yarattıkları iletişim, işbirliği, dayanışma, varsayma süreçlerinden oluşan, hoşgörüye, liderliğe, motivasyona dayalı, bilgi üretilen ve bilginin kullanıl- dığ1 süreçleri tarif eder. Bunlara ilave olarak; Astone ve diğ. (1999) sosyal sermayenin üç boyutunun olduğunu savunmuştur. Bunlar; ilişkiye dayalı sosyal sermaye formları, bireyler arası etkileşime dayalı sosyal sermayenin kalitesi ve sosyal sermayenin etkilerinden oluşan kaynaklardır. Astone'nin bu yaklaşımı okul, öğrenci ve eğitim perspektifinde ele alındığında öğrencilerin sosyal sermayelerinin aynı toplumsal ve eğitim sistemi içinde oluştuğu/geliştiği, hatta, aile içerisinde başlayan ilişki, iletişim ve etkileşim sürecinin, öğrencinin okula başlamasıyla form değiştirerek, öğretmen, akran, sınıf/okul arkadaşı boyutuna dönüştüğü hatta daha ileriki aşamalarda buna hobi grupları, temsil edilen/dahil olunan sosyal gruplar, yerel yönetim ilişkisi, üye olunan mesleki ve/veya belirli bir misyonu üstlenen sivil toplum kuruluşları, komşular, içinde yaşanılan toplum ve muhitteki diğer insanlar boyutuna dönüşerek gelişir. Tüm bu unsurları, çocukluk döneminden başlayarak tüm bireylerin öğrencinin akademik ve sosyal başarısı dahil bireyin yaşamındaki diğer tüm başarıların sebep-sonuç değerini oluşturan boyutlar olarak da görmek gereklidir (Huang, 2008; Astone ve diğ., 1999).

Coleman'ın insanların oluşturduğu örgütleri insan doğasından kaynaklanan duyguların gücünden soyutlayarak anlamaya çalışmak dar görüşlülük olarak tanımlamıştır (Töremen, 2002). Bu açıdan bakıldığında eğitim dahil olmak üzere tarafı olduğumuz veya dahil olduğumuz tüm süreçlerde aynı insani tepkiler ve ihtiyaçlarla davranışlar ortaya koyarız. Karşlıklı işbirliğine, desteğe, bağlantı kurmaya, güvene, adalete, onaylanmaya ve kabul görmeye bir insan olarak daima ihtiyacımız vardır. Bu sebeple insanların ve kurumların karşılıklı birbirlerine güvendiği, birbirleriyle özdeşleştikleri, bütünleştikleri, güçlü sosyal bağlarla birbirlerine bağlı oldukları sosyal ve kurumsal uygulamalarda daha sağlıklı örgütlenme ve daha fazla verimliliğin ortaya çıkması beklen- 
mektedir. Diğer bir deyişle sosyal sermaye örgütlerin, toplulukların, komşuların, ailenin ve tüm insan gruplarını içine alan yapıların günlük yaşamlarının içinde yatan "insanda canlandırdığı duygular" olarak görülebilir. Sokakta, markette, koridorda karşılaşan bireylerin birbirlerini nasıl algıladıkları, nasıl selamladıkları, birbirlerine söyledikleri cümlelerin kurgulanma ve söylenme biçimleri, sorulara verilen cevaplar, soru sorma biçimleri, karşılıklı niyet, yaratılan duygusal atmosfer, örgütlerin, toplumların sosyal sermaye stokunu ifade eder (Cohen ve Prusak, 2001). Toplumların yapısına bağlı olarak insanın olduğu her yerde doğal olarak sosyal sermaye vardır ve güven, karşılıklı anlayış, işbirliği, ortak değerler ve ortak davranışla yaratılan sosyal sermaye miktarı arttırılabilir veya azaltılabilir (Lee ve Croninger, 2001). Bu açılardan bakıldığında; eğitimin bir toplumda devralınan, yaratılan ve sürdürülen sosyal sermayeyi arttırmadaki en temel ve belirleyici unsur olduğu söylenebilir.

Yerli ve yabancı literatürde akademik başarıyı sorgulayan birçok çalışma yapılmıştır. Bunlardan bazıları; Çelenk'in (2003) okul ve aile dayanışmasını ele aldığı çalışma, Hill ve Taylor'un (2004) ailenin okuldaki eğitim süreçlerine dahil olması ve öğrencilerin başarıları arasındaki ilişkiyi ele aldığı çalışma, Gelbal'ın (2008) öğrencilerin sosyo-ekonomik özellikleriyle bir dersteki başarısını sorguladığı çalışma, Keçeki-Kaysılı'nın (2008) akademik başarı ve ailenin eğitim süreçlerine katılımını işlediği çalışma, Tomul ve Çelik'in (2009) öğrencilerin sosyo-ekonomik seviyeleri ile başarıları arasındaki karşılaşmayı ele aldığı, Schlee ve diğ.'nin (2009) ebeveynlerin sahip oldukları sosyal ve kaynak sermayesinin çocukların akademik başarılarını nasıl etkilediğini ele aldıkları çalışma, Yücel ve Koç'un (2011) öğrencilerin cinsiyetleri ile bir dersin başarısını yordama gücü arasındaki ilişkiyi sorguladıkları çalışmadir.
Sosyal sermaye eğitim ilişkisini sorgulayan bazı çalışmalar; Güllüpınar ve İnce'nin (2014) yaptıkları Şanlıurfa'daki eğitim eşitsizliğini kültürel yapı, sosyal sermaye ve yapısal faktörlerin sosyolojik analizi ile sorguladığı çalışma, Töremen'in (2002) okullardaki sosyal sermaye kavramını kavramsal olarak sorguladığı çalışma, Drukker ve diğ.'nin (2003) çocukların sağlıkla ilintili yaşam kaliteleri, çevre, sosyoekonomik değişim ve sosyal kapitalin sorgulandığ çalışma, Töremen'in (2004) yaptığı Elazığ ili örneğinde ilköğretim okullarının sahip oldukları sosyal sermaye konusunda öğretmen görüşlerinin sorgulandığı çalışma, Farmer-Hinton ve Adams'in (2006) kolej hazırlık sınıflarındaki siyahi öğrencilerine yapılan rehberlik, sosyal sermaye ve kolejlere hazırlıklarının sorguladığı çalışma, Garcia-Reid'in (2007) düşük gelirli Hispanik kızların okula adaptasyonları ve sosyal sermaye arasındaki ilişkinin sorgulandığı çalışma, Anderson'un (2008) sosyal sermaye ve öğrenme ilişkisinin Latin Amerika'daki ilköğretim okullarındaki sonuçlarının verildiği çalışmadır.

Bunların yanında sosyal sermaye ile akademik başarıyı ilişkilendirerek sorgulayan çalışmalar çok değildir. Bunlardan bazıları; Valenzuela ve Dornbush'un (1994) Meksika ve Anglosakson kökenli çocukların akademik başarısında aile ilişkileri ve sosyal sermayenin öneminin sorgulandığı çalışma, Huang'ın (2008) Norveçli ilköğretim öğrencileri üzerinde yaptığı ve sosyal sermaye ile başarıyı arasındaki ilişkiyi sorguladığı çalışma, Ardahan'ın (2012) sosyal sermaye, yaşam doyumu ve akademik başarı ilişkisini Akdeniz Üniversitesi, BESYO örneğinde sorguladığ çalışmadır. Çalışmaların üzerinde odaklandığı ve bulguladığı bu çalışmalarda elde edilen sonuçlar; sosyal sermaye düzeyinin yüksek olduğu bireyler, örgütler ve toplumlarda sosyal sermayeyi oluşturan unsurlar; sivil toplum kuruluşlarına katılım, yerel yönetime katılım, bir yere aidiyet, komşuluk ve 
farklılı̆̆a hoş görü, sosyal temsiliyet, çevreye ve insan duyulan güven ve sosyal temsilciliğin de yüksek olduğudur. Buna ilave olarak sosyal sermaye düzeyi arttıkça başarı ihtiyacı ve talebi artacak, akademik başarı dahil, iş başarısı, insan sermayesi, toplumların sporda, sanatta, kültürel yaşamda oluşturdukları katma değer, toplumların ve bireylerin bilgi üretme ve kullanma düzeyi, rekabet avantajı ve yaşam doyum düzeyi de yüksek olacaktır. Sosyal sermaye ve akademik başarı arasında doğrusal bir ilişki olduğunu çalışmalarda bulgulamıştır.

\section{YÖNTEM}

\subsection{Araștırmanın Amacı}

Bu çalı̧̧manın amacı Antalya örneğinde ilköğretim sekizinci sınıf öğrencilerinin sosyal sermaye profillerini belirlemek, sosyal sermaye ve başarı durumlarını çeşitli demografik değişkenlere göre irdelemektir

\subsection{Araştırma Modeli}

$\mathrm{Bu}$ çalışma tanımlayıcı araştırma modelinde yapılmış ve Antalya ilinde olan üç devlet, iki özel okul öğrencileriyle sınırlandırılmıştır.

\section{3 Örneklem Grubu}

Çalışmanın örneklem grubu; Antalya'da bulunan üç devlet (Beşkonak İÖO, Dr. Galip Kahraman İÖO, Barbaros İÖO) ve iki özel okul (AKEV Koleji IOÖO, Antalya Koleji ÏÖO) toplam beş farklı ilköğretim okulunun sekizinci sınıfındaki tüm (162 kız ve 163 erkek, toplam 325) öğrencilerden oluşmaktadır. Araştırmada yüz yüze görüşme yöntemi uygulanmıştır. Bu aşamada 01-Şubat-2014/30-Nisan-2014 tarihleri arasında yüz yüze doldurulan 335 anket kontrol edildikten sonra istatistikî analize uygun olan 325 anket değerlendirilmeye alınmıştır.

\subsection{Veri Toplama Aracı}

Çalışmada Huang (2008) tarafından geliştirilen ve Ardahan ve Ezici (2014) tarafından Türkçe adaptasyonu yapılan İlköğretim İkinci Kademe Öğrencileri Sosyal Sermaye Ölçeği, Bilgin ve Kaynak (2008) tarafından geliştirilen ve bireylerin algılanan başarı düzeyini ölçen Başarı Ölçeği ve demografik bilgilerin alınacağ 1 soru formu kullanılmıştır. Ölçek maddelerinin değerlendirilmesinde 5'li ölçek kullanılmıştır ve "1Kesinlikle Katılmıyorum, 5-Kesinlikle Katılıyorum" olarak ağırlıklandırılmıştır.

\subsection{Verilerin Analizi}

Verilerin istatistiksel analizinde tanımlayıcı istatistiksel yöntemlerin yanında ve Kolmogorov Smirnov normallik sınamasında tüm karş1laşmalarda normal dağılım koşulları yerine geldiği için iki değişken arasındaki karşılaştırmalarda One Way ANOVA testi, independent sample T-test, iki değişken arasındaki korelasyona bakmak için Pearson Corelation Test, gruplar arasındaki farkın belirlenmesinde Tukey-b testi kullanılmış ve sonuçlar 0.01 ve 0.05 anlamlılık düzeyinde değerlendirilmiştir.

\subsection{Kullanılan Ölçeklerin Geçerlilik Güvenir- lilik Bilgileri}

İlköğretim öğrencilerinin sosyal sermaye değerini belirlemek için kullanılan “İlköğretim Öğrencileri Sosyal Sermaye Ölçeğinin"geçerlilik güvenirlilik bilgileri Tablo-1'de verilmiştir. Tablodan da görülebileceği gibi; Kaiser-MayerOlkin Örneklem Yeterlilik Ölçümü 0.864, Bartlett Küresellik testi $\mathrm{p}<0.05$, toplam Cronbach's Alpha katsayısı 0.873, toplam açılanan varyans \%58,90 olarak bulunmuştur. Bu değer ölçeğin istatistiki olarak yeterli güvenirlilikte ve geçerlilikte olduğunu göstermektedir. Algılanan başarıyı ölçen Başarı ölçeği Cronbach's Alpha katsayısı 0.746 bulunmuştur ve geçerli düzeydedir. 
Tablo-1. İlköğretim Öğrencileri Sosyal Sermaye Ölçeği ve Başarı Ölçeği'nin Geçerlilik Güvenirlilik Bilgileri

\begin{tabular}{|c|c|c|}
\hline \multicolumn{2}{|c|}{ Kaiser-Mayer-Olkin Örneklem Yeterlilik Ölçümü } & 0.864 \\
\hline & Yaklaşık Ki-kare & 2145,677 \\
\hline \multirow[t]{2}{*}{ Bartlett Küresellik Testi } & Serbestlik derecesi & 153 \\
\hline & Anlamlılık & 0.000 \\
\hline \multicolumn{2}{|c|}{ Ölçeğin Toplam Cronbach's Alpha değeri } & 0,873 \\
\hline \multicolumn{2}{|c|}{ Ölçeğin Açıklanan Varyansı } & 58,900 \\
\hline \multicolumn{2}{|c|}{ Faktör “İyi Ebeveyn İlişkisi” Cronbach's Alpha değeri } & 0,828 \\
\hline \multicolumn{2}{|c|}{ Faktör “Arkadaşlardan Yardım İsteme” Cronbach's Alpha değeri } & 0,715 \\
\hline \multicolumn{2}{|c|}{ Faktör "Sosyal Problemlere Duyarlılık" Cronbach's Alpha değeri } & 0,766 \\
\hline \multicolumn{2}{|c|}{ Faktör "Öğretmenlerden Yardım İsteme” Cronbach's Alpha değeri } & 0,818 \\
\hline \multicolumn{2}{|c|}{ Algılanan Başarı Ölçeği Cronbach's Alpha değeri } & 0746 \\
\hline
\end{tabular}

\section{BULGULAR}

$\mathrm{Bu}$ bölümde araştırma verilerine uygulanan analizlerin sonuçları verilmektedir. Katılımcıların demografik bilgileri Tablo-2'de verilmiştir. Tablodan da görülebileceği gibi; araştırmaya katılan öğrencilerin \%50,2'si erkek, $\% 49,8^{\prime} \mathrm{i}$ kadın, \%57,2'si devlet okulunda, \%42,8'i özel okulda, \%19,4'ü Beşkonak İÖO, \%11,1'i Dr. Galip Kahraman İÖO, \%26,8'i Barbaros İÖO, \%15,7'si AKEV Koleji, \%27,1'i Antalya Kolejinde okumaktadırlar. Öğrencilerin $\% 76,6$ 'sı 14 yaşında iken, annelerinin \%55,7'si ev hanımı, babalarının \%28,3'ü kendi işini yapmakta, annelerin eğitim durumunda yaklaşık bir homojenlik varken, babaların eğitim durumunda $\% 47,1$ ile üniversite mezunları çoğunluktadır. Ailenin toplam geliri açısından bakıldığında \%50,8'i 3000 TL ve altı geliri vardır. Öğrenciler; komşularla karşılaştırıldığında ailenin ekonomik durumunda (\%55,4 aynı kaldı) ve son iki yılla karşılaştırıldığında ailenin ekonomik durumunda (\%56,0 aynı kaldı) özel bir değişiklik olmadığını belirtmişlerdir. Öğrenciler, derslerdeki başarı durumlarının son üç yıl karşılaştırıldığında $\quad \% 55,7^{\prime}$ si $\quad$ arttığını söylemişlerdir. Sekizinci sınıf Bahar dönemi müfredat derslerindeki ortalama 75 ve üstüdür.
Öğrencilerin Sosyal Sermaye alt boyutları, Toplam Sosyal Sermaye ve Başarı Durumu, bu değişkenler arasındaki korelasyon, bu değişkenlerin Okul Türü, Okullara göre karşılaştırılmaları Tablo-3'de verilmiştir. Tablodan da görülebileceği gibi; öğrencilerin Sosyal Sermayeleri Başarı Durumları yüksek değildir. Öğrencilerin Sosyal Sermaye düzeyleri Okul türüne göre karşılaştırıldığında sadece "Öğretmenden Yardım İsteme" alt boyutunda istatistiki olarak fark vardır ve farklılık devlet okulları lehinedir. Buna göre devlet okullarındaki öğrenciler özel okuldaki öğrencilerle göre öğretmenleriyle daha yakından iletişim kurabilmekte, onlara daha fazla güvenebilmekte ve hatta gerektiğinde okul ve gelecekle ilgili konularda öğretmenleriyle daha fazla konuşabilmektedir. Bu devlet okullarında okuyan öğrencilerin kişilik özelliklerinden kaynaklanabileceği gibi öğretmenlerin öğretim görevlerini yapmadaki ilave çabalarından da kaynaklanabilir.

Öğrencilerin Sosyal Sermaye düzeyleri Okula göre karşılaştırıldığında sadece “Öğretmenden Yardım İsteme" alt boyutunda ve Başarı Durumlarına göre istatistiki olarak anlamlı fark vardır ve farklılık Beşkonak İÖO ve Dr. Galip Kahraman İÖO lehinedir. Beşkonak İÖO köy okulu, Dr. Galip Kahraman İÖO ise çoğunluğu 
düşük gelir gurubu ailelerin çocuklarının devam ettiği okullardır. Bu okuldaki öğrencilerin diğer okuldaki öğrencilere göre öğretmenleriyle daha yakından iletişim kurabilmekte, onlara daha fazla güvenebilmekte ve hatta gerektiğinde okul ve gelecekle ilgili konularda öğretmenleriyle daha fazla konuşabilmektedir. Başarı durumları açısından bakıldığında ortalamalar arasındaki istatistiki anlamlı farklılık Beşkonak İÖO, Dr. Galip Kahraman İÖO ve AKEV Koleji öğrencilerinin lehinedir.

Tablo-2. Katılımcıların Demografik Özellikleri

\begin{tabular}{|c|c|c|c|c|c|}
\hline Cinsiyet & $\mathrm{f}$ & $\%$ & Annenin Çalıștığı Yer & $\mathrm{f}$ & $\%$ \\
\hline Erkek & 163 & 50,2 & Kamu Sektörü & 47 & 14,5 \\
\hline $\mathrm{K}_{1 \mathrm{Z}}$ & 162 & 49,8 & Özel Sektör & 36 & 11,1 \\
\hline Okul Türü & $f$ & $\%$ & Ev Hanımı & 181 & 55,7 \\
\hline Özel Okul-Kolej & 139 & 42,8 & Kendi İşi & 21 & 6,5 \\
\hline Devlet Okulu & 186 & 57,2 & Emekli & 16 & 4,9 \\
\hline Babanın Çalıştığı Yer & $f$ & $\%$ & İşsiz & 13 & 4,0 \\
\hline Kamu Sektörü & 64 & 19,7 & Serbest Meslek & 11 & 3,4 \\
\hline Özel Sektör & 68 & 20,9 & Ailenin Aylık Geliri & $\mathbf{f}$ & $\%$ \\
\hline Kendi İşi & 92 & 28,3 & 2000 TL ve alt 1 & 112 & 34,5 \\
\hline Emekli & 18 & 5,5 & $2001-4000 \mathrm{TL}$ & 79 & 24,3 \\
\hline İşsiz & 6 & 1,8 & 4001 TL ve üstü & 134 & 41,2 \\
\hline Serbest Meslek & 77 & 23,7 & Anne Eğitim Durumu & $\mathbf{f}$ & $\%$ \\
\hline Derslerin Geçme Notu & Ort. & St.SP & İlköğretim & 104 & 32,0 \\
\hline Matematik & 75,83 & 19,76 & Lise ve Dengi & 102 & 31,4 \\
\hline Türkçe- Dil ve Anlatım & 85,14 & 13,87 & Üniversite ve Üstü & 119 & 36,6 \\
\hline İnkılap Tarihi & 81,70 & 15,75 & Babanın Eğitim Durumu & $\mathbf{f}$ & $\%$ \\
\hline Fen Bilgisi & 80,14 & 16,41 & İlköğretim & 87 & 26,8 \\
\hline Beden Eğitimi & 98,32 & 3,95 & Lise ve Dengi & 85 & 26,2 \\
\hline $\begin{array}{l}\text { Din Kültürü ve Ahlak } \\
\text { Bil }\end{array}$ & 88,34 & 11,90 & Üniversite ve Üstü & 153 & 47,1 \\
\hline Resim-Müzik & 98,32 & 4,49 & Komşularla Karşılaştırıldığında A. Ek. D. & $f$ & $\%$ \\
\hline Teknoloji-Tasarım & 96,42 & 7,84 & Daha Kötü & 18 & 5,5 \\
\hline Yaş & $\mathbf{f}$ & $\%$ & Aynı & 180 & 55,4 \\
\hline 13 & 46 & 14,2 & Daha İyi & 127 & 39,1 \\
\hline 14 & 249 & 76,6 & Ailenin Ekonomik Durumu Son İki Yıl & $\mathbf{f}$ & $\%$ \\
\hline 15 & 30 & 9,2 & Daha Kötü & 34 & 10,5 \\
\hline Okullar & $\mathbf{f}$ & $\%$ & Aynı & 182 & 56,0 \\
\hline Beşkonak İÖO & 63 & 19,4 & Daha İyi & 109 & 33,5 \\
\hline $\begin{array}{l}\text { Dr. Galip Kahraman } \\
\text { İÖO }\end{array}$ & 36 & 11,1 & Derslerdeki Başarı Durumu Son Üç Yıl & $\mathbf{f}$ & $\%$ \\
\hline Barbaros İÖO & 87 & 26,8 & Daha Kötü & 26 & 8,0 \\
\hline AKEV Koleji & 51 & 15,7 & Ayn1 & 118 & 36,3 \\
\hline Antalya Koleji & 88 & 27,1 & Daha İyi & 181 & 55,7 \\
\hline TOPLAM & 325 & 100,0 & TOPLAM & 325 & 100,0 \\
\hline
\end{tabular}

Öğrencilerin Sosyal Sermaye alt boyutları ve Toplam Sosyal Sermaye düzeyleri ile öğrencilerin algıladıkları Başarı Durumları arasındaki oldukça güçlü bir korelasyon vardır. Buna göre öğrencilerin; ebeveynleri ile kurguladığı iletişimin kalitesi ve düzeyi arttıkça Başarı Durumu \%49,6 artmakta, öğrenciler akranlarıyla, aileleriyle, arkadaşlarıyla ve öğretmenleriyle sınıf 
ortamında ve/veya dışarıda sosyal problemleri konuştukça, öğrenciler sosyal problemlere ilgili oldukça Başarı Durumu \%43,10 artmakta, öğrencilerin okul arkadaşlarıyla iletişimi, onlara olan güveni ve yardım isteme düzeyi arttıkça Başarı Durumu \%33,6 artmakta, öğrencilerin öğretmenleriyle iletişimi, onlara olan güveni ve yardım isteme düzeyi arttıkça Başarı Durumu $\% 48,4$ artmakta. Öğrencilerin Toplam Sermaye düzeyi arttıkça, Başarı Durumları \%57,8 artmaktadır.

Tablo 3. Öğrencilerin Sosyal Sermaye ve Başarı Durum Düzeyleri ve Bu değerlerin Okul Türüne ve Okullara Göre Karşılaştırmaları, Başarı Durumuyla Korelasyonu

\begin{tabular}{lcccc}
\hline $\begin{array}{l}\text { Sosyal Sermaye Alt Boyutları } \\
\text { ve Başarı Durumu }\end{array}$ & Ort \pm SS & $\begin{array}{c}\text { Okul Türüne } \\
\text { Göre } \\
\text { Karşllaştırma (t) }\end{array}$ & $\begin{array}{c}\text { Okullara Göre } \\
\text { Karşılaştırma (F) }\end{array}$ & $\begin{array}{c}\text { Başarı Durumuy- } \\
\text { la } \\
\text { Korelasyonu }\end{array}$ \\
\hline $\begin{array}{l}\text { Iyi Ebeveyn İlişkisi } \\
\text { Sosyal Problemlere Duyarlılık }\end{array}$ & $3,56 \pm 0,84$ & 0,019 & 0,257 & $0,496^{* *}$ \\
$\begin{array}{l}\text { Arkadaşlardan Yardım } \\
\text { İsteme }\end{array}$ & $3,29 \pm 0,90$ & $-1,730$ & 1,171 & $0,431^{* *}$ \\
$\begin{array}{l}\text { Öğretmenlerden Yardım } \\
\text { İsteme }\end{array}$ & $3,80 \pm 1,04$ & 0,147 & 0,377 & $0,336^{* *}$ \\
$\begin{array}{l}\text { Toplam Sosyal Sermaye } \\
\text { Başarı Durumu }\end{array}$ & $3,40 \pm 1,14$ & $-2,076^{*}$ & $4,409^{*}$ & $0,484^{* *}$ \\
\hline${ }^{*}$ p $<0.05-{ }^{* *} p<0.01$ & $-1,267$ & & \\
\end{tabular}

Öğrencilerin Sosyal Sermaye düzeyleri ve Başarı Durumunun Anne-Baba eğitim durumu ve Anne ve Babanın Çalıştıkları yerlerle karşılaştırılması Tablo-4'de verilmiştir. Tablodan da görülebileceği gibi Sosyal Sermaye alt boyutlarından "Sosyal Problemlere Duyarlılık" ve "Öğretmenden Yardım İsteme" ile Toplam Sosyal Sermaye ve Başarı Durumları Anne eğitimiyle karşılaştırıldığında ortalamalar arasında istatistiki olarak fark vardır ve farklılık annesi ilkokul mezunu olan öğrencilerin lehinedir. Bunun nedeni ilkokul mezunu olan annelerin büyük ölçüde kendileri okuyamadıkları için çocuklarını başarılı olma konusunda daha fazla motive etmeleri ve öğrenciler ders konusunda ebeveynlerinden yeterli destek alamayacakları için o eksik kısmı öğretmenlerinden telafi etme istekleri olabilir. Benzer durum babası ilkokul mezunu olan öğrencilerde de vardır. Sosyal Sermaye alt boyutlarından "Sosyal Problemlere Duyarlılık", "Arkadaştan Yardım İsteme" ve "Öğretmenden Yardım İsteme" ile Toplam Sosyal Sermaye ve Başarı Durumları Baba eğitimiyle karşılaştırıldığında ortalamalar arasında istatistiki olarak fark vardır ve farklılık babası ilkokul mezunu olan öğrencilerin lehine bir farklılık vardır. Bunun nedeni ilkokul mezunu olan babaların büyük ölçüde kendileri okuyamadıkları için çocuklarını başarılı olma konusunda daha fazla motive etmeleri ve öğrenciler ders konusunda ebeveynlerinden yeterli destek alamayacakları için o eksik kısmı öğretmenlerinden telafi etme istekleri olabilir.

Sosyal Sermaye alt boyutları, Toplam Sosyal Sermaye ve Başarı Durumları ile Annenin çalışma durumları karşılaştırıldığında ortalamalar arasında istatistiki olarak anlamlı bir farklılık yoktur. Buna göre çalışsın, çalışmasın tüm anneler çocuklarıyla yakından ilgilenmektedir. Sosyal Sermaye alt boyutları, Toplam Sosyal Sermaye ve Başarı Durumları ile Babanın çalışma durumları karşılaştırıldığında "Sosyal Problemlere Duyarlılık" alt boyutunda ortalamalar arasında istatistiki olarak anlamlı bir farklılık vardır ve farklılık işsiz ve kamuda çalışan babaların aleyhinedir. Buna göre babası işsiz olan ve kamuda çalışan öğrenciler sosyal problemlere daha az duyarlı, arkadaşları, aileleri ve öğretmenleriyle sosyal problemleri daha az konuşmaktadır. Bunun en önemli 
nedeni bu özellikteki babaların ailede sosyal problemleri konuşmaması olabilir.

Tablo 4. Öğrencilerin Sosyal Sermaye ve Başarı Durumları ve Bu değerlerin Anne Baba Eğitim Durumu ve Çalıştıkları Yerlere Göre Karşılaştııılması

\begin{tabular}{|c|c|c|c|c|}
\hline $\begin{array}{l}\text { Sosyal Sermaye Alt Boyutları } \\
\text { ve Başarı Durumu }\end{array}$ & $\begin{array}{c}\text { Annenin } \\
\text { Eğitimine Göre } \\
(\mathrm{F})\end{array}$ & $\begin{array}{c}\text { Babanın } \\
\text { Eğitimine Göre } \\
(\mathrm{F})\end{array}$ & $\begin{array}{c}\text { Annenin } \\
\text { Çalıştığ1 Yere } \\
\text { Göre (F) } \\
\end{array}$ & $\begin{array}{c}\text { Babanın } \\
\text { Çalıştığı Yere } \\
\text { Göre (F) } \\
\end{array}$ \\
\hline İyi Ebeveyn İlişkisi & 0,351 & 1,632 & 0,457 & 0,595 \\
\hline $\begin{array}{l}\text { Sosyal Problemlere Duy- } \\
\text { arlılık }\end{array}$ & $3,168^{*}$ & $4,768^{*}$ & 0,807 & $2,249^{*}$ \\
\hline $\begin{array}{l}\text { Arkadaşlardan Yardım } \\
\text { İsteme }\end{array}$ & 1,823 & $0,172^{*}$ & 0,550 & 0,519 \\
\hline $\begin{array}{l}\text { Ö̈̆gretmenlerden Yardım } \\
\text { İsteme }\end{array}$ & $10,723^{*}$ & $14,793^{*}$ & 0,672 & 0,921 \\
\hline Toplam Sosyal Sermaye & $4,177^{*}$ & $6,334^{*}$ & 0,479 & 1,307 \\
\hline Başarı Durumu & $4,553^{*}$ & $6,610^{*}$ & 0,789 & 0,991 \\
\hline
\end{tabular}

Öğrencilerin Sosyal Sermaye boyutları ve Başarı Durumunun öğrencilerin cinsiyetine göre ve ailelerin aylık toplam geliriyle karşılaştırılması Tablo-5'de verilmiştir. Tablodan da görülebileceği gibi Sosyal Sermaye alt boyutlarından "Sosyal Problemlere Duyarlılık" "Arkadaştan Yardım İsteme" boyutunda Öğrencilerin cinsiyetlerine göre istatistiki olarak anlamlı bir farklılık vardır ve farklılık kız öğrencilerin lehinedir. Buna göre kız öğrenciler erkek öğrencilere göre daha fazla okul arkadaşlarıyla anlaml, doyumlu iletişim kurabilmekte, gerektiğinde onlardan yardım isteye bilmekte ve onlara daha fazla güvenebilmektedir.

Sosyal Sermaye alt boyutlarından "Sosyal Problemlere Duyarlılık”, “Öğretmenden Yardım İsteme" boyutunda ve Öğrencilerin Toplam Sosyal Sermaye düzeylerinde öğrencilerin ailelerin aylık toplam gelirlerine göre istatistiki olarak anlamlı bir farklılık vardır. "Sosyal Problemlere Duyarlılık" ve "Öğretmenden Yardım İsteme" alt boyutlarında ve Öğrencilerin Toplam Sosyal Sermaye düzeylerindeki farklılık düşük gelire sahip (2000 TL ve altı) öğrencilerin lehinedir. Buna göre düşük gelir gurubu ailelerin çocukları öğretmenleriyle daha anlam- l1, doyumlu iletişim kurabilmekte, gerektiğinde onlardan yardım isteye bilmekte ve onlara daha fazla güvenebilmekte, sosyal problemlere daha duyarlı, arkadaşları, öğretmenleri, aile ve diğer kişilerle sosyal problemleri daha fazla konuşmaktadırlar. Buna ilave olarak düşük gelir düzeyli ailelerin çocuklarının sosyal sermaye değerleri veya sosyal sermaye stokları diğer çocuklarınkine göre daha yüksektir.

Öğrencilerin Sosyal Sermaye boyutları ve Başarı Durumunun öğrencilerin ekonomik durumlarının komşularla, ailenin son iki yılıyla ve derslerdeki başarılarının son üç yılla kıyaslanması durumuyla karşılaştırılması Tablo-6'da verilmiştir. Tablodan da görülebileceği gibi Sosyal Sermaye boyutları ve Başarı Durumunun ekonomik durumu komşularla karşılaştırıldığında, durumları iyileşen, değişmeyen ve kötüleşen öğrencilerin sosyal sermaye düzeyleri ve başarı durumları arasında istatistiki olarak anlamlı bir farklılık yoktur. Sosyal Sermaye boyutları ve Başarı Durumunun ailenin ekonomik durumu son iki yılla karşılaştırıldığında, durumları kötüleşen öğrencilerin Sosyal Sermaye alt boyutlarından "İyi Ebeveyn İlişkisi" boyutunda istatistiki olarak anlamlı bir farklılık vardır. Buna göre 
ekonomik durumları son iki yılla karşılaştırıldığında kötüleşen öğrencilerin aileleriyle kurguladıkları anlamlı, doyumlu ve yeterli iletişim boyutunda ve ailelerin öğrencil-

Tablo 5. Öğrencilerin Sosyal Sermaye ve Başarı Durumları ve Bu değerlerin Cinsiyete ve Ailenin Aylık Toplam Gelirine Göre Karşılaştırılması

\begin{tabular}{|c|c|c|}
\hline $\begin{array}{l}\text { Sosyal Sermaye Alt Boyutları ve Başarı Du- } \\
\text { rumu }\end{array}$ & $\begin{array}{l}\text { Cinsiyete Göre } \\
(\mathrm{t})\end{array}$ & $\begin{array}{l}\text { Gelire Göre } \\
\text { (F) }\end{array}$ \\
\hline İyi Ebeveyn İlişkisi & $-0,440$ & 0,245 \\
\hline Sosyal Problemlere Duyarlılık & $-0,770$ & $3,262^{*}$ \\
\hline Arkadaşlardan Yardım İsteme & $-3,360^{*}$ & 0,884 \\
\hline Öğretmenlerden Yardım İsteme & $-0,922$ & $7,702^{*}$ \\
\hline Toplam Sosyal Sermaye & $-1,892$ & $3,862^{*}$ \\
\hline Başarı Durumu & 0,372 & $5,092^{*}$ \\
\hline
\end{tabular}
erinde de bir azalma olmuştur. erin okul yaşamları ve eğitimleriyle ilgilenmel-

${ }^{*} \mathrm{p}<0.05-{ }^{* *} \mathrm{p}<0.01$

Sosyal Sermaye boyutları ve Başarı Durumunun öğrencinin derslerdeki başarı durumunun son üç yılla karşılaştırıldığında, başarı durumu kötüleşen öğrencilerin aleyhine Sosyal Sermaye alt boyutlarından "İyi Ebeveyn İlişkisi", "Öğretmenden Yardım İsteme", "Toplam Sosyal Sermaye" ve Başarı Durumu boyutlarında istatistiki olarak anlamlı bir farklılık vardır. Buna göre; başarı durumları son üç yılla karşılaştırıldığında kötüleşen öğrencilerin aileleriyle kurguladıkları anlamlı, doyumlu, yeterli iletişim boyutunda ve ailelerin öğrencilerin okul yaşamları ve eğitimleriyle ilgilenmelerinde de bir azalma olmuştur. İlave olarak son üç yılda başarı durumları kötüleşen öğrencilerin öğretmenleriyle kurguladıkları iletişim, onlara güvenme ve gerektiğinde onlardan yardım alma durumunda da bir azalma olmuştur. Bu azalmalar doğal olarak öğrencinin toplam sosyal sermayesini ve başarı durumunu azaltmıştır.

Tablo 6. Öğrencilerin Sosyal Sermaye ve Başarı Durumları ve Bu değerlerin Ekonomik Durumun Komşularla ve Son İki Yılla Kıyaslaması Durumu ile Başarı Durumunun Son Üç Yılla Karşılaştırılması

\begin{tabular}{|c|c|c|c|}
\hline $\begin{array}{l}\text { Sosyal Sermaye Alt Boyutları ve } \\
\text { Başarı Durumu }\end{array}$ & $\begin{array}{c}\text { Ekonomik Durumu } \\
\text { Komşularla } \\
\text { Karşılaştırma } \\
\text { (F) }\end{array}$ & $\begin{array}{c}\text { Ekonomik Durumu } \\
\text { Ailenin Son } 2 \text { Yılıyla } \\
\text { Karşılaştırma } \\
\text { (F) }\end{array}$ & $\begin{array}{c}\text { Başarı Durumunu } \\
\text { Son } 3 \text { Yılıyla } \\
\text { Karşılaştırma } \\
\text { (F) }\end{array}$ \\
\hline İyi Ebeveyn İlişkisi & 0,499 & $2,995^{*}$ & $5,120^{*}$ \\
\hline Sosyal Problemlere Duyarlılık & 0,078 & 1,145 & 1,692 \\
\hline Arkadaşlardan Yardım İsteme & 0,056 & 0,055 & 1,965 \\
\hline Öğretmenlerden Yardım İsteme & 0,929 & 0,924 & $3,184^{*}$ \\
\hline Toplam Sosyal Sermaye & 0,134 & 0,345 & $4,327^{*}$ \\
\hline Başarı Durumu & 0,767 & 2,818 & $6,183^{*}$ \\
\hline
\end{tabular}

Öğrencilerin derslerdeki başarı durumlarının okul türüne ve okullara göre karşılaştırılmaları Tablo-7'de verilmiştir. Tablodan da görülebileceği gibi; tüm derslerde özel okulların başarıları devlet okullarına göre fazladır ve aralarındaki fark istatistiki olarak anlamlıdır. Benzer şekilde derslerin başarı durumlarının okullara göre karşılaştırılmalarında Beşkonak İÖO, Dr. Galip Kahraman İÖO ve Barbaros İÖO'da okuyan öğrencilerin derslerdeki başarı durumları neredeyse tüm derslerde özel okullara göre düşüktür ve farklılık istatistiki olarak anlamlıdır. 
Tablo 7. Öğrencilerin Derslerdeki Başarı Durumlarının Okul Türüne ve Okul Adına Göre Karşılaştırılmasi

\begin{tabular}{|c|c|c|c|c|c|c|c|c|c|}
\hline \multirow{2}{*}{$\begin{array}{l}\text { Derslerdeki } \\
\text { Başarı Du- } \\
\text { rumları }\end{array}$} & \multicolumn{3}{|c|}{ Okul Türüne Göre } & \multicolumn{6}{|c|}{ Okul Adına Göre } \\
\hline & $\begin{array}{c}\text { Özel } \\
\text { Oku } \\
1\end{array}$ & $\begin{array}{l}\text { Devlet } \\
\text { Okulu }\end{array}$ & $\mathrm{t}$ & $\begin{array}{c}\text { Beşko- } \\
\text { nak } \\
\text { IÖK }\end{array}$ & $\begin{array}{l}\text { Dr.Galip } \\
\text { KH. }\end{array}$ & $\begin{array}{c}\text { Barbaros } \\
\text { İÖO }\end{array}$ & $\begin{array}{l}\text { AKEV } \\
\text { Koleji }\end{array}$ & $\begin{array}{c}\text { Antalya } \\
\text { Koleji }\end{array}$ & $\mathrm{F}$ \\
\hline Matematik & $\begin{array}{c}87,9 \\
3\end{array}$ & 66,80 & $11,228^{*}$ & 60,21 & 64,78 & 72,40 & 82,47 & 91,09 & $41,969^{*}$ \\
\hline $\begin{array}{l}\text { Dil ve An- } \\
\text { latım }\end{array}$ & $\begin{array}{c}92,8 \\
0\end{array}$ & 79,41 & $9,788^{*}$ & 74,65 & 77,81 & 83,52 & 89,78 & 94,55 & $32,426^{*}$ \\
\hline $\begin{array}{l}\text { İnkılap Tari- } \\
\text { hi }\end{array}$ & $\begin{array}{c}90,8 \\
5\end{array}$ & 74,87 & $10,453^{*}$ & 69,40 & 70,86 & 80,48 & 86,73 & 93,24 & $40,220^{*}$ \\
\hline Fen Bilgisi & $\begin{array}{c}90,7 \\
4\end{array}$ & 72,23 & $12,118^{*}$ & 67,89 & 70,75 & 75,98 & 87,57 & 92,58 & $43,141^{*}$ \\
\hline $\begin{array}{l}\text { Beden } \\
\text { Eğitimi }\end{array}$ & $\begin{array}{c}99,7 \\
0\end{array}$ & 97,28 & $5,702^{*}$ & 96,06 & 96,67 & 98,43 & 99,49 & 99,82 & $12,566^{*}$ \\
\hline Din-Ahlak B & $\begin{array}{c}93,0 \\
9\end{array}$ & 84,79 & $6,615^{*}$ & 85,57 & 80,31 & 86,08 & 90,37 & 94,66 & $14,342^{*}$ \\
\hline $\begin{array}{l}\text { Resim- } \\
\text { Müzik }\end{array}$ & $\begin{array}{c}99,6 \\
3\end{array}$ & 97,34 & $4,675^{*}$ & 96,89 & 97,86 & 97,46 & 99,29 & 99,82 & $5,873^{*}$ \\
\hline $\begin{array}{l}\text { Tekn. } \\
\text { Tasarım }\end{array}$ & $\begin{array}{c}99,3 \\
4\end{array}$ & 94,24 & $6,114^{*}$ & 93,89 & 96,97 & 93,37 & 98,51 & 99,82 & $11,293^{*}$ \\
\hline
\end{tabular}

Öğrencilerin derslerdeki başarı durumlarının ailenin ekonomik durumları, anne-baba eğitim durumlarına göre karşılaştırılmaları Tablo-8' de verilmiştir. Tablodan da görülebileceği gibi; tüm derslerde ailenin gelir düzeyi, anne ve baba eğitim durumları yükseldikçe öğrencilerin derslerdeki başarı oranları yükselmektedir ve eğitim durumları arasındaki farklılık istatistiki olarak anlamlıdır .

Tablo 8. Öğrencilerin Derslerdeki Başarı Durumlarının Ailenin Gelir Düzeyleri, Anne Baba Eğitim Durumuna Göre Karşılaştırılması

\begin{tabular}{|c|c|c|c|c|c|c|c|c|}
\hline \multirow[b]{2}{*}{$\begin{array}{l}\text { Derslerdeki } \\
\text { Başarı Durumları }\end{array}$} & \multicolumn{4}{|c|}{ Annenin Eğitim Durumu } & \multicolumn{4}{|c|}{ Babanın Eğitim Durumu } \\
\hline & $\begin{array}{l}\text { İlk. } \\
\text { Mez }\end{array}$ & $\begin{array}{l}\text { Lise } \\
\text { Dengi }\end{array}$ & $\begin{array}{l}\text { Üni. } \\
\text { Üstü }\end{array}$ & $\mathrm{F}$ & $\begin{array}{l}\text { İlk. } \\
\text { Mez }\end{array}$ & $\begin{array}{l}\text { Lise } \\
\text { Dengi }\end{array}$ & $\begin{array}{l}\text { Üni. } \\
\text { Üstü }\end{array}$ & $\mathrm{F}$ \\
\hline Matematik & 62,56 & 76,95 & 86,48 & $54,366^{*}$ & 60,86 & 73,04 & 85,90 & $63,215^{*}$ \\
\hline Dil ve Anlatım & 76,05 & 87,42 & 91,12 & $43,994^{*}$ & 75,15 & 84,40 & 91,22 & $48,311^{*}$ \\
\hline İnk1lap Tarihi & 71,15 & 83,99 & 88,96 & $47,681^{*}$ & 70,15 & 79,62 & 89,42 & $57,298^{*}$ \\
\hline Fen Bilgisi & 69,10 & 81,18 & 88,92 & $54,144^{*}$ & 68,18 & 77,49 & 88,42 & $59,401^{*}$ \\
\hline Beden Eğitimi & 96,86 & 98,80 & 99,18 & $11,373^{*}$ & 96,24 & 98,75 & 99,25 & $18,642^{*}$ \\
\hline Din Kültürü ve Ahlak Bilgisi & 84,12 & 89,01 & 91,45 & $11,487^{*}$ & 83,08 & 87,11 & 92,01 & $17,940^{*}$ \\
\hline Resim-Müzik & 96,94 & 98,78 & 99,13 & $7,658^{*}$ & 96,69 & 98,78 & 98,99 & $8,245^{*}$ \\
\hline \multirow[t]{2}{*}{ Teknoloji ve Tasarım } & 93,63 & 97,25 & 98,14 & $10,607^{*}$ & 93,85 & 96,52 & 97,83 & $7,436^{*}$ \\
\hline & \multicolumn{8}{|c|}{ Ailenin Ekonomik Durumu } \\
\hline Derslerdeki Başarı Durumları & \multicolumn{2}{|c|}{2000 TL ve $<$} & \multicolumn{2}{|c|}{$2001-4000 \mathrm{TL}$} & \multicolumn{2}{|c|}{4000 TL ve $>$} & \multicolumn{2}{|c|}{$\mathrm{F}$} \\
\hline Matematik & \multicolumn{2}{|c|}{62,82} & \multicolumn{2}{|c|}{73,47} & \multicolumn{2}{|c|}{88,10} & \multicolumn{2}{|c|}{$73,287^{*}$} \\
\hline Dil ve Anlatım & \multicolumn{2}{|c|}{76,65} & \multicolumn{2}{|c|}{84,09} & \multicolumn{2}{|c|}{92,84} & \multicolumn{2}{|c|}{$56,090^{*}$} \\
\hline İnk1lap Tarihi & \multicolumn{2}{|c|}{71,54} & \multicolumn{2}{|c|}{80,59} & \multicolumn{2}{|c|}{90,84} & \multicolumn{2}{|c|}{$63,920^{*}$} \\
\hline Fen Bilgisi & \multirow{2}{*}{\multicolumn{2}{|c|}{69,96}} & \multicolumn{2}{|c|}{77,09} & \multicolumn{2}{|c|}{90,46} & \multicolumn{2}{|c|}{$70,569^{*}$} \\
\hline Beden Eğitimi & & & \multicolumn{2}{|c|}{98,09} & \multicolumn{2}{|c|}{99,78} & \multicolumn{2}{|c|}{$20,695^{*}$} \\
\hline
\end{tabular}




\begin{tabular}{lllll} 
Din Kültürü ve Ahlak Bilgisi & 84,43 & 85,39 & 93,34 & $23,086^{*}$ \\
Resim-Müzik & 96,83 & 98,13 & 99,68 & $13,311^{*}$ \\
Teknoloji ve Tasarım & 94,55 & 94,80 & 98,94 & $12,633^{*}$ \\
\hline${ }^{*} \mathrm{p}<0.05$ &
\end{tabular}

\section{TARTIŞMA VE SONUÇ}

Bu çalışmada; İlköğretim sekizinci sınıf öğrencilerinin sosyal sermaye ve başarı düzeyleri ve bu değişkenlerin çeşitli demografik değişkenlerle aralarındaki ilişki ve farklılık ortaya konulmuştur.

Sosyal sermaye; öğrencilerin bir birey olarak ebeveynleri, aileleri, akranları, yaşadığı çevredeki diğer insanlar, okul/sınıf arkadaşları, öğretmenler arasında kendi ve başkalarının yaşamları ve yaşarken karşılaşılan her tür konu, olay ve sosyal problemlerle ilgili olarak kurguladıkları ilişki, iletişim, etkileşim ve kalitesi düzeyi olarak görüldüğünde, araştırma sonuçlarıyla ilgili olarak her birey kendisi için yeterli, anlamlı düzeyde ilişki kurguladıkları ve bunun okul türüne, okullara göre değişmediğini söylemek mümkündür. $\mathrm{Bu}$ sonuçlar Huang'in (2008) sonuçlarıyla örtüşmektedir. Buna göre, eğer doğal afetler, savaşlar, otokratik yönetim biçimi, din, örf adet ve gelenekler gibi çok özel durumlar ve müdahaleler söz konusu değilse, bu durumun birçok toplum için de geçerli olduğunu söylemek mümkündür.

Bunlara ilave olarak; devlet okullarında ve çoğunlukla düşük gelir düzeyindeki ailelerin çocuklarının devam ettiği okullarda ve öğrenciöğretmen ilişkisine yatırım yapan okullarda öğrencilerin öğretmenleriyle etkili ve doyumlu iletişim geliştirmesi ve onlardan yardım istemeleri şaşırtıcı değildir. Hala Anadolu'da öğretmen, öğrencilerin ailesinde bulamadı̆̆ı etkileşimi kurabildiği en birincil kaynaktır. Bu sebeple ona güvenmesi, onla her konuyu konuşması ve akademik geleceği için ondan destek alması beklenen bir durumdur. Buna ilave olarak; öğrencilerin anne ve babalarının eğitim düzeyleri ile öğrencilerin sosyal problemlere olan ilgisi, öğretmenden yardım isteme, toplam sosyal sermaye ve başarı durumu arasında anlamlı bir ilişkinin olması beklenen bir durumdur. Diğer taraftan eğitimde fırsat eşitliği yaklaşımına göre öğrenci başarısının okul türüne veya okulların bulunduğu bölgeye göre değişmemesi beklenmektedir. Fakat bu durum ülkemizde istenilen düzeyde değildir (Berberoğlu ve Kalender, 2005). Okullara göre öğrenci başarı düzeyleri okulların sosyo-demografik özelliklerine göre değişmektedir. Düşük gelir düzeyli ailelerin çocuklarının okudukları okullar (Beşkonak İÖO ve Dr. Galip Kahraman İÖO) ve gelir durumu normal düzeyde olan öğrencilerin derlerdeki başarıları her ne kadar özel okuldaki öğrencilerden düşük olsa da öğrencilerin okullarının ve ailecek sahip olunan imkanlarda diğer okullarda okuyan öğrencilere göre kendilerini başarılı algılamaktadırlar. Bu öğrencilerin başarı ihtiyacından kaynaklanabileceği gibi okulun insan sermayesinden de (öğretmen ve yöneticilerin başarıya odaklanmış olmaları) kaynaklanabilir.

Mevcut çalışmada ailenin gelir düzeyi, anne ve babanın eğitim seviyesi arttıkça öğrencilerin derslerdeki başarı düzeylerinin arttığı fakat öğrencinin akademik başarının azaldığı bulgulanmıştır. Schlee ve diğ. (2009), Gelbal (2008) ve Keçeli-Kaysılı (2008); anne ve babanın eğitim düzeyleri ve ailenin sosyo-ekonomik düzeyleri arttıkça öğrencilerin başarısının arttığını bulgulamışlardır ve mevcut araştırmanın sonuçları literatürdeki çalı̧̧malarla uyuşmaktadır. Eğitimi bir yatırım olarak tanımlandığında ailelerin gelir ve eğitim düzeyleri arttıkça, eğitim malzemesi desteği alma, yardımcı ders materyali alma, dershane, özel ders gibi destekleyici unsurları satın alma ve/veya yatırım yapma imkanı da artmakta ve doğal olarak öğrencilerin başarı düzeyleri de artmaktadır. Fakat bu- 
nun yanında gelir düzeyi, anne-baba eğitim düzeyi artan ailelerin çocuklarının başarı algıları diğerlerine göre düşüktür. Bunun en önemli nedeni mevcut eğitim sisteminde yarış atına döndürülen öğrencilerin en iyiyi arama, başkalarıyla rekabette daha iyi olma anlayışının bir yansıması olarak, öğrencilerin ve ailelerin öğrencilerin derslerdeki başarısını yeterli bulmamasından kaynaklanabilir.

Düşük eğitim düzeyli ailelerin çocuklarının ailesindeki eğitim düzeyi düştükçe öğretmenden yardım isteme öğretmeni bir kurtarıcı olarak görme düzeyi artmaktadır. Bu durum öğrencinin, ailede gerçekleştiremediği akademik ve sosyal doyumu okulda öğretmeniyle gidermeyi istemesinden kaynaklanabilir. Bunun yanında; gelir düzeyi düştükçe öğrencilerin sosyal problemlere daha duyarlı olması aile, arkadaş, öğretmen, akranlarla sosyal problemleri daha fazla konuşuyor olmaları, başarı ihtiyacı ve başarı durumunun yüksek olması Türkiye gerçeğinde şaşırılacak bir durum değildir. Özellikle düşük gelir düzeyine sahip öğrencilerin akademik başarılarının yüksek olması, aileden kendilerine devredilecek bir ekonomik değerin olmamasına bağlanıp, kendilerine başarılı olmalarından başka seçenek tanımlamamaktadırlar. Hatta bu durum aile bireyleri tarafından kendilerine önemli bir uyaran ve motivasyon unsuru olarak da kullanilıyor olabilir. Başarmaktan başka şansının olmadığını gören öğrenciler başarılı olma konusunda kendilerini daha güçlü motive edeceklerdir.

Kız öğrencilerin sosyal sermaye alt boyutlarından "Arkadaşlardan Yardım İsteme" boyutunda erkek öğrencilerden daha iyi olması kadınların duygusal zekalarının (İşmen, 2001) ve iletişim yeteneklerinin(Huang, 2008; Gülbahçe, 2010; Görmüş ve diğ. 2013) erkeklerden daha yüksek olmasına bağlanabilir. Buna ilave olarak cinsiyete göre başarı düzeylerinin cinsiyete değişmemesi eğitimde fırsat eşitliği teorisiyle uyumlaşmaktadır (Berberoğlu ve Kalender,
2005). Diğer taraftan sosyal sermaye düzeyinin cinsiyete göre değişmemesi Huang'ın da (2008) bulguladığı bir sonuçtur.

Mevcut araştırma sonuçlarına göre, ailesinin ekonomik durumunda son iki yılda bir iyileşmenin olduğunu belirten öğrencilerin; “İyi Ebeveyn İlişkisi" boyutunda aileleriyle olan ilişkilerinin, ailelerin öğrencilerin eğitimlerine olan ilgisi, desteği ve nitelikli zaman ayırmasinın artması öğrencinin ailesiyle daha anlamlı ve doyumlu iletişim, ilişki düzeyinde olmasını, ebeveynlerin öğrencinin okul yaşamına daha fazla dahil olmasına sebep olmuştur. Bu, Schlee ve dĭg. (2009), Gelbal (2008) ve KeçeliKaysılı'nın (2008) çalışmalarında belirtilen ailenin ekonomik durumunda bir iyileşmenin olması öğrencinin ailesiyle kuracağı iletişim ve ailenin öğrencinin okul yaşamına dahil olması$\mathrm{n} ı$ arttıracağı sonuçlarıyla desteklenen bir durumdur.

Buna ilave olarak son üç yılda başarı durumunda bir iyileşme gören öğrencilerin, "İyi Ebeveyn İlişkisi" ve "Öğretmenden yardım İsteme" boyutlarında aileleriyle olan ilişkilerinin, ailelerin öğrencilerin eğitimlerine olan ilgisi, desteği ve nitelikli zaman ayırmasının, öğrencinin ailesiyle kurduğu anlamlı ve doyumlu iletişim düzeyinin, ebeveynlerin öğrencinin okul yaşamına dahil olma düzeyinin, öğretmenle kendi arasında kurgulayacağı iletişim, ilişki ve güven düzeyinin, toplam sermaye düzeyinin ve öğrencinin başarı düzeyinin artması, değişkenler arasında kurgulanan ilişkinin mevcut araştırma sonuçlarıyla doğrulandığı anlamina gelmektedir.

Mevcut araştırma sonuçlarına göre öğrencilerin Sosyal Sermaye alt boyutları ve Toplam Sosyal Sermaye düzeyleri ile Başarı Durumları arasındaki oldukça güçlü bir korelasyon olduğudur. Diğer bir deyişle; öğrencilerin; ebeveynleri ile kurguladığı iletişimin kalitesi ve düzeyi arttıkça, öğrencileri akranlarıyla, aileleriyle, arkadaşlarıyla ve öğretmenleriyle sınıf ortamında 
ve/veya dışarıda sosyal problemleri konuştukça, öğrenciler sosyal problemlere ilgili oldukça, öğrencilerin okul arkadaşlarıyla ve öğretmenleriyle iletişimi, onlara olan güveni ve yardım isteme düzeyi başarı durumları artmaktadır. Bu durum Huang (2008), Valenzuela ve Dornbush (1994), Berbereoğlu ve Kalender (2005) ve Kotaman'ın (2008) yaptıkları araştırmaların sonuçlarıyla örtüşmektedir.

Sonuç olarak; sosyal sermaye ve akademik başarı arasında anlamlı bir ilişki vardır. Öğrencilerin sosyal sermayelerini geleceğe yatırım olarak görüp onu arttırmanın yolları aranmalıdır. Sosyal sermaye arttırıldığında başarı da bununla birlikte gelecektir. Diğer taraftan başarı durumu ile okullar arasında bir farklılık vardır. Başarı düzeyi yüksek okullar daha çok gelir düzeyi düşük sosyal çevresi olan okullar ve öğrenci başarısı üzerine yatırım yapmış okullardır.

Anne ve babanın eğitim düzeyinin ve gelir düzeylerinin düşük olması öğrencinin ailede, kendi sosyal çevresinde bulamadığ desteği almak için öğrencileri öğretmenleriyle daha etkileşim içinde, anlamlı ve doyumlu bir ilişkiye zorlarken, ebeveynlerin okula ve eğitim süreçlerine daha fazla dahil olması, öğrenci ile ilişkisi ve etkileşimin artması doğal olarak öğrencinin akademik başarısını da arttırmaktadir.

Sosyal sermaye ve başarı arasındaki anlamlı ilişkiden sonra beklenen faydaları elde etmek için; mutlaka öğrencilerin hem ailede hem de yaşanılan yer ve okul çevresinde güven ortamının yaratılması ve sürdürülmesi, insan ilişkilerine dayalı bir dünya kurulmasını, farklılığa daha hoşgörülü bir ortamın yaratılmasını, komşuluk ilişkilerine yatırım yapılması, ailenin çocukla anlamlı, doyumlu, kalite düzeyi yüksek iletişim ortamının yaratılması, aile bireylerinin öğrencinin okulla olan ilişkilerine daha fazla dahil olasının, öğretmen öğrenci, öğretmen aile etkileşiminin yaratılması, bunun için eğitimin tüm taraflarının işbirliği içinde olması gereklidir.

İster aile içinde isterse aile dışında birbirlerini tanıyan ya da tanımayan tüm bireyler arası ilişki ve iletişimin yaratılması, güçlendirilmesi ve yaygınlaştırılmasında aktif veya pasif katılımlı her türlü kültürel, sanatsal, sportif, el becerilerine dayalı rekreatif etkinlikler araç olarak kullanılabilir. Bu amaçla; merkezi ve yerel otorite, özel ve kamu sektörü, sivil toplum kuruluşları ve diğer tüm kurumlar kendileriyle her düzeyde ilişkili bireyler ve kurumlar rekreatif etkinlikler düzenlemeli, düzenleyen yapıları ve kişileri desteklemeli, düzenlenen etkinliklere dahil olmaya birey ve kurumları motive etmelidirler. Bu konuda; ister özel isterse devlete ait eğitim kurumları öğrencileri aileleriyle, öğretmenleriyle, diğer öğrenciler ve akranlarıla, aile bireylerini okulla ve diğer aile bireyleriyle bir araya getireceği ve bireyleri daha da yakınlaştıracağı rekreatif etkinlikleri kendileri düzenleyebileceği gibi, üniversiteler, belediyeler, gençlik merkezleri, eğitim kurumları, özel ve kamu sektörü, sivil toplum kuruluşları ve diğer kurumların liderlik üstlenerek gerçekleştirecekleri etkinliklere de katılabilirler. Hatta bu konuda bahsedilen tüm kurumlarla stratejik işbirliği yapabilirler. 


\section{Kaynakça}

Astone, N.M., Constance, A.N., Schoen, R. ve Kim, Y.J. (1999). Family demography, social theory, and investment in social capital. Population and Development Review, 25:1-31.

Anderson, J.B. (2008). Social capital and student learning: Empirical results from Latin American primary schools, Economics of Education Review 27 (2008):439-449.

Ardahan, F. (2012). Sosyal Sermaye, Yaşam Doyumu ve Akademik Başarı İlişkisi: Akdeniz Üniversitesi, BESYO Örneği, 12. Uluslararası Spor Bilimleri Kongresi, 12-14 Aralık 2012, Denizli-Türkiye.

Ardahan, F. (2013) Rekreasyonel Etkinliklere Katılmanın Örgüte, Mesleğe Bağlllık İle Yaşam Doyumu ve Başarım Algısı Üzerindeki Etkisi: Antalya Eğitim Araştırma Hastanesi Örneği”", 21 th European Association For Sport Management (EASM) Türkçe Ön Konferansı Bildiriler Kitabı, Uluslararası Spor Ekonomisi ve Yönetimi Konferansı Kongre, 11 Eylül 2013, İstanbul Lütfü Kırdar Fuar ve Kongre Merkezi, İstanbul.

Ardahan, F. ve Ezici, M.N. (2014). Adaption of "Social Capital Scale for Second Grade Students" Validity and Reliability Study. Sakarya University Journal of Education, 4(3): 92-107.

Astone, N.M., Constance, A.N., Schoen, R. ve Kim, Y.J. (1999). Family demography, social theory, and investment in social capital. Population and Development Review,25: 1-31.

Bilgin, N. ve Kaynak, R. (2008). Sosyal Sermaye Faktörlerinin İş Başarısına Etkisi: Üniversite Çalışanları Üzerine Ampirik Bir Çalışma, C.Ü. Sosyal Bilimler Dergisi, Mayıs 2008, 32(1):29-38.

Berberoglu, G. ve Kalender, İ. (2005). Investigation of Student Achievement Across Years, School Types And Regions: The SSE And PISA Analyses. Eğitim Bilimleri ve Uygulama, 4 (7): 21-3.

Breen, R. and Jonsson, J.O. (2005). Inequality of opportunity in comparative perspective: Recent research on educational attainment and social mobility. Annual Review of Sociology, 31, 223-243.

Buru-Bellat, M. (2004). Social inequality at school and educational policy. Fundamentals of Educational Planning. Paris: IIEP, UNESCO.

Cohen, D. ve Prusak, L. (2001). Kavrayamadığımız Zenginlik. Kuruluşların Sosyal Sermayesi, İstanbul: MESS Yayınları.

Coleman, J. (1988). Social Capital in The Creation Of Human Capital. American Journal of Sociology, 94, 94-120.

Çelenk, S. (2003). Okul Başarısının Ön Koşulu: Okul Aile Dayanışması, İlköğretim-Online, 2(2): 28-34.

Drukker, M., Kaplan, C., Feron, F. ve Os, J.V. (2003). Children's health-related quality of life, neighbourhood socio-economic deprivation and social capital. A contextual analysis, Social Science \& Medicine, 57: 825-841.

Erdoğdu, Y.M. (2006). Yaratıcılık İle Öğretmen Davranışları ve Akademik Basarı Arasındaki İlişkiler, Sosyal Bilimler Dergisi, 5(17) : 95-106.

Farmer-Hinton R.L. ve Adams, T.L. ( 2006). Social Capital and College Preparation: Exploring the Role of Counselors in a College Prep School for Black Students, The Negro Educational Review, 57(1-2): 101-116.

Fukuyama, F. (1999). Social Capital and Civil Society (Conference), The Institute of Public Policy, George Mason University, October 1, 1999, https://www.imf.org/external/pubs/ft/seminar/1999 /reforms/fukuyama.htm, Erişim Tarihi: 04.07.2012

Garcia-Reid, P. (2007). Examining Social Capital as a Mechanism for Improving School Engagement Among Low Income Hispanic Girls, Youth and Society, 39(2):164 -181.

Gelbal, S. (2008). The Effect of Socio-Economic Status of Eighth Grade Students On Their Achievement in Turkish, Education and Science, 33(150): 1-13. 
Görmüş, A.Ş., Aydın, S. ve Ergin, G.(2013).İ̧̧letme Bölümü Öğrencilerinin İletişim Becerilerinin Cinsiyet Rolleri Bağlamında İncelenmesi, Sosyal Bilimler Dergisi, 15(1): 109-128. DOI NO: 10.5578/JSS.6357

Gülbahçe, Ö. (2010) K.K. Eğitim Fakültesi Öğrencilerinin İletişim Becerilerinin İncelenmesi, Atabesbd 2010; $12(2): 12-22$

Güllüpınar, F. ve İnce, C. (2014). Şanlıurfa'da Eğitimsel Eşitsizliklerin Yeniden Üretimi: Kültürel Yapı, Sosyal Sermaye ve Yapısal Faktörlerin Sosyolojik Analizi, Eğitim Bilim ve Toplum Dergisi, 12(46):84-121.

Güzel, C.I. and Berberoglu, G. (2005). An analysis of the programme for international student assessment 2000 (PISA 2000) mathematical literacy data for Brazilian, Japanese and Norwegian students. Studies in Educational Evaluation, 31, 283-314.

Harding, D.J. (2003). Counterfactual models of neighborhood effects: The effects of neighborhood poverty on dropping out and teenage pregnancy. American Journal of Sociology, 109, 368-385.

Heral I. (2006). Sosyal Sermaye, http://www.eastweststudies.org/tr/makale_detail.php?makale=58 \&tur=10025.03.2006

Hill, N.E. ve Taylor, L.C. (2004). Parental School Involvement and Children's Academic Achievement: Pragmatics and Issues, Psychological Science, 13(4):161-164.

Huang, L. (2008). Social Capital and Student Achievement in Norwegian Secondary Schools, Learning and Individual Differences, (Online 2008: http://dx.doi.org/10.1016/j.lindif.2008.11.004)

İşmen, A.E. (2001), Duygusal Zeka ve Problem Çözme, M.Ü. Atatürk Eğitim Fakültesi Ĕ̆gitim Bilimleri Dergisi, 13: 111-124.

Kaya, N. ve Selçuk, S. (2007). Bireysel Başarı Güdüsü Organizasyonel Bağlllığı Nasıl Etkiler? Doğuş Üniversitesi Dergisi, 8 (2): 175-190.

Keçeli-Kaysılı, B. (2008). Akademik Başarının Arttırılmasında Aile Katılımı, Ankara Üniversitesi Eğitim Bilimleri Fakültesi, Özel Ĕ̆itim Dergisi, 9 (1): 69-83.

Keskin, G. ve Sezgin, B. (2009). Bir Grup Ergende Akademik Basarı Durumuna Etki Eden Etmenlerin Belirlenmesi, Fırat Sağlık Hizmetleri Dergisi, 4(10): 3-18.

Kotaman, H. (2008). Türk Ana Babalarının Çocuklarının Eğitim Öğretimlerine Katılım Düzeyleri, Eğitim Fakültesi Dergisi, 21 (1):135-149

Lee, V.E. ve Croninger, R.C. (2001). The Elements of Social Capital in the Context of Six High Schools, Journal of Socio-Economics, 30(2):165-169.

Lin, N. (2000). Inequality in social capital. Contemporary Sociology, 29, 785-795.

McDonough, P.M. (1997). Choosing colleges: How social class and schools structure opportunity. Albany, NY: State University of New York Press.

Meier, A. (1999). Social capital and academic achievement among adolescents. Working Paper 99-18. University of Wisconsin-Madison: Center for Demography and Ecology.

Morgan, S.L. (2001). Counterfactuals, causal effect heterogeneity, and the Catholic school effect on learning. Sociology of Education, 74, 341-374.

Putnam, R.D., Leonardi, R. ve Nanetti, R.Y. (1993). Making democracy work: Civic traditions in modern Italy. Princeton, NJ: Princeton University Press.

Sandefur, G.D. and Wells, T. (1999). Does family structure really affect educational attainment. Social Science Research, 28, 331-357.

Sandefur, G.D., Meier, A. and Campbell, M. (2006). Family resources, social capital and college attendance. Social Science Research, 35, 525-553. 
Schlee, B.M., Mullis, A.K. ve Shriner, M. (2009). Parents social and resource capital: Predictors of academic achievement during early childhood, Children and Youth Services Review, 31:227-234.

Schoen, R., Kim, Y.J., Nathoanson, C.A., Fields, J. ve Astone, N.M. (1997). Why do Americans want children? Population and Development Review, 23, 333-358.

Teachman, J., Paasch, K. ve Carver, K. (1996). Social capital and dropping out of school early, Journal of Marriage and the Family, 58, 773-783.

Thrupp, M. (1999). Schools making a difference: Let's be realistic! Buckingham: Open University Press.

Tomul, E. ve Çelik, K. (2009). The relationship between the students' academics achievement and their socioeconomic level: cross regional comparison, World Conference on Educational Sciences, Procedia Social and Behavioral Sciences 1 (2009): 1199-1204.

Töremen, F. (2002). Okullarda Sosyal Sermaye: Kavramsal Bir Çözümleme, Kuram ve Uygulamada Eğitim Yönetimi, 32:556-573.

Töremen, F. (2004). İlköğretim Okullarının Sahip Oldukları Sosyal Sermaye Konusunda Öğretmen Görüşleri: Elazığ İli Örneği, XIII. Ulusal Eğitim Bilimleri Kurultayı, 6-9 Temmuz, 2004, İnönü Üniversitesi, Eğitim Fakültesi, Malatya.

Valenzuela, A. ve Dornbush, S.M. (1994). Familism and Social Capital in Academic Achievement of Mexican Origin and Anglo Adolescent, Social Sciences Quarterly, 75(1):18-36.

Yücel, Z. ve Koç, M. (2011). İlköğretim Öğrencilerinin Matematik Dersine Karşı Tutumlarının Başarı Düzeylerini Yordama Gücü ile Cinsiyet Arasındaki İlişki, İlköğretim Online, 10(1):133-143. 


\section{Extended Summary}

There are many types of capital like; physical capital, economic capital, human capital, healthy capital, cultural capital and social capital which consist of the total the quality of social relation between all individuals.

Social capital can be accepted as the measure of the social link or social networks created between individuals. Social interaction effect positive or negative individual's life, give them chance or not. At the same time social capital has positive effect on individual's life satisfaction, neighbor relations, academic or professional life and leisure. It affects positively children's social and academic life.

Social Capital of adults were measured by nine sub-factor given in Ardahan (2012) as; (a) Participation in the Local Community which explain the voluntarily participation to local comity, (b) Neighborhood Connections which explain the neighborhood relation, (c) Being the property of somewhere which explain the work/school relation and property, (d) Tolerance of Diversity which explain the acceptable level of diversity, (e) Being a member of nongovernmental organizations which explain the active participation of legal local and social community, (f) Feelings of Trust which explain the trust to other, (h) Feelings of Safety which explain the safety level of residence, (i) Community initiative which explain the responsibility of others,and (j) Being representative of social context which explain the helping others. Social Capital of students was measured by four sub-factor given in Ardahan and Ezici (2014) as; (a) "good child-parent interaction" which explain the level of relationship and communication between child and adults, (b) "Sensitive to Social Problems" which explain the sensitive level of child to social problems in his/her school, social and family life, (c) "seeking helps from friends" which explain the level of satisfaction, adequacy and relation with school friends, level of trust to them, and when it is necessary seeking help from friends (d) "seeking helps from teachers" which explain the level of satisfaction, adequacy and relation with teachers, level of trust to them, and when it is necessary seeking help from teachers.

Many researchers concluded that there are many factors which effects students' academic achievement. Majors are income of family, safety of residence and neighborhood, the communication and interaction level between child and parents, education level of adults, learning capacity of child, personality, endowments and accomplishments, paradigm, expectations of parents and children from education, synchronization between children, parents, peers, school friends, teachers.

The purpose of the present study is to define the profile of Eighth Class Students and to examine the social capital and student achievements level of students with respect to some demographic variables. In this study, Social Capital Scale which was developed by Huang (2008) and adapted to Turkish population by Ardahan and Ezici (2014) and achievement inventory developed by Bilgin and Kaynak (2008) were used. This is a descriptive study and sampling group consisted of 162 girls, 163 boys and totally 325 students who were studying in the five different schools (three state, two private schools) which have different environments.

In this study, In the evaluation of the Social Capital Scale Items 5 point Likert $(1$ = Definitely Disagree .. 5 = Definitely agree) were used. The data collected by face to face method between the dates 01st January and 30th April 2014. In order to analyze the data, the descriptive statistics methods, ANOVA test, Independent Samples $t$ test, for correlation Pearson Correlation Test and to explain relation be- 
tween dependent and independent variables Tukey-b test was used. Results have been assessed according to significant levels 0.01 and 0.05 .

As a result of this study, the strong correlation was found between social capital level in all sub dimension also) and students achievements. It is vitally important that social capital must be accepted as an investment and must be examined to increase the level of it. When social capital level of a student or society was increased, achievements would follow it. On the other hand, there was statistically meaningful difference between school types on the student's achievements level in favor of schools which has disadvantages environment and which students family has low income or which have made adequate investment for students achievements. The parents who has lower education level and lower income level, forces the student to establish adequate or more relation with teacher to make compensation of academic support which cannot be realized in family or social environment of students. When family attendance to school and the quality and satisfaction level of parent-student's relation increase, it affects positively the student's achievement.

In addition to these results, recreational activities are vitally important role and can be used as a tool to create and sustain the social relation, interaction and communication between children, peers, school friends, teachers, adults and the other individuals. For this reason; university, municipalities, youth centers, educational institutions, private and public sector, nonprofit organizations and the other authorities must take responsibility to create leadership to organize recreational activities and solutions. 